\title{
AF MADS LANGES BALINESISKE BREVARKIV \\ $\mathrm{AF}$
}

\section{Leo Buschardt}

/ads Johansen Lange blev født d. 18. sept. I807 i Rudkøbing på 1 Langeland. Både på fædrene og mødrene side havde hans slægt givet sig af med skibsfart og handel, en vej som også Lange betrådte allerede I824, da han blev forhyret med tremasteren "Norden“, som foretog en rakke rejser på Ostindien. Om hans eventyrlige liv og virksomhed som skibsreder og storhandelsmand inden for det indonesiske område, med faste forbindelser til Kina og Europa, har forfatteren Aage Krarup Nielsen skrevet den kendte bog „Mads Lange til Bali. En dansk Ostindiefarers Liv og Eventyr", 1925, 4. opl. I944, hollandsk oversættelse 1928 , islandsk oversattelse 1946 . Med rette er dette værk blevet så uhyre læst. Det må værdsættes $\mathrm{i}$ lige høj grad for sin pålidelige dokumentation som for sin levende skildring såvel af det givne miljo som af Mads Langes fangslende og usædvanlige personlighed.

Af hans data skal her i korthed anføres, at han fra 1834 drev handelsvirksomhed i stor stil fra øen Lombok, men efter en rakke voldsomme hæendelser i året 1839 forlagde residensen til øen Bali, hvor den egentlige blomstring af hans virksomhed fandt sted. I året $\mathrm{I} 843$ fik han hollandsk borgerskab, fra året 1844 var han den hollandsk-indiske regerings repræsentant på Bali. I de hollandske kolonikrige mod øens indfødte fyrster spillede han flere gange en afgørende rolle som formidler og mægler, hvad han kunde gøre $\mathrm{i}$ kraft af den store indflydelse og personlige prestige, som han besad både blandt Balineserne og Europæerne. Han døde d. 13. maj 1 856 , og hans grav kan endnu ses på Balis sydkyst ved byen Kuta, stedet for hans virksomhed, hvor den hollandske regering i 1927 lod rejse et højt og stateligt mindesmarke til hans ære.

Man må beklage, at Krarup Nielsen under affattelsen af sin bog ikke til disposition havde en lille pakke breve, der nu findes på Det kongelige Bibliotek, så meget mere som disse breve efter al sandsynlighed allerede dengang fandtes i landet. Det drejer sig om seks breve fra balinesiske 
afsendere, skrevet på balinesisk eller malajisk sprog med den balinesiskjavanske skrift. Brevene er efter balinesisk skik skrevet på blade af lontarpalmen (Borassus flabellifer), præparerede på en særlig måde og skåret til i en størrelse, der varierer mellem $2 \mathrm{I}$ til $26 \mathrm{~cm}$ gange 3,5 til $4 \mathrm{~cm}$. Selve skriften er indridset med en lille kniv (pengutik), hvorefter bladene gnides med kemiri-aske. De fardige breve omsvøbes med en slags konvolut af torrede blade. På de fleste af brevene har Mads Lange desuden selv med blyant eller blæk skrevet notater, som regel gengivelser eller oversættelser af brevenes indhold på dansk eller engelsk.

Brevene er skanket til biblioteket af Fru overbibliotekar H. O. Lange, og pakken, hvori de fandtes, bærer påskriften: „Fundet i Professorinde Schat Petersens Efterladenskaber". Fru Anine Schat Petersen, enke efter den kendte teolog professor Louis Schat Petersen (1851-1903), døde i 1936. Hvorledes brevene er kommet i familien Schat Petersens cje, vides ikke med sikkerhed. Frøken Agnete Schat Petersen, datter af ovennæunte, mener, at de uden tvivl har været det meget længe, og at der er en mulighed for, at de i slutningen af forrige århundrede sammen med andre orientalske genstande er skanket til professor Schat Petersen af skibsreder Chr. Sass, der i sin ungdom selv foretog rejser til Ostindien.

I 1952 blev brevene sendt til den hollandske videnskabsmand Dr. P. Voorhoeve, Leiden, som er kyndig på disse områders sprog, historie og kultur. Dr. Voorhoeve har udarbejdet transkriptioner og oversættelser til brevene samt givet udførlige kommentarer til deres indhold, idet han herunder har søgt supplerende oplysninger hos H. T. Damsté, den nylig afdøde resident på Bali og Lombok, og hos sin kollega, specialist i balinesisk sprog, Fru J. H. Hooykaas-van Leeuwen Boomkamp.

I det folgende skal jeg give et referat af Dr. Voorhoeves arbejde, kun suppleret med enkelte kommenterende tilføjelser. Oversættelsen fra det hollandske sprog er foretaget af min kollega bibliotekar Tue Gad.

BREv I. Består af to lontarblade knyttet sammen med en tynd snor. Sproget er malajisk. Afsenderen er Mads Langes første hustru, en balineserinde, om hvem intet hidtil har været kendt udover, at han med hende havde to sønner. Afsenderinden har ikke selv skrevet brevet har vel ikke behersket skrivekunsten - og har blot efter sit navn undertegnet det med et kryds, iøvrigt er brevet skrevet og udformet af en professionel skriver, som har suppleret det diktat, han fik, med nogle konventionelle høflighedsudtryk og talemåder.

Transkription: Twan Lange, sudagar bsar di Kotta, Bali Badung, djwa adanja. Skarang adalah saja mambilang kapạ̣a twan, didalem 
ini surât, jang dahulu, témpo blun saja dapet anak, dngen twan, jang twan punja niat kapaḍa saja, djikalo twan sampé dapet anak laki dwa, twan mawo tjariken sajâ kembang mâs, dngen satu pending, makâ skarang dari itu, itulah sajâ mambri inget kapaḍa twan, sebap skarang twan suda dapet anak (verso) laki dwa, djwa adanja. Sahdan lagi skarang maka adalah sajâ minta parbanjak kapạ̣a twan, djikalo twan ada sukâ dan kesyan, kapạ̣a saja, saja minta satu kréta ketjil, mawo bikin maènnja twan punja anak, dan lagi saja minta kapaḍa twan, dahulu ada twan kasih satu orgol kapaḍa saja, skarang djikalo ada twan suka, itu orgol, saja minta kumbali, kapaḍa twan, djwa a(2)danja. Sahdan lagi, saja minta ampun parbanjak-banjak kapạ̣a twan, djikalo twan ada suka, dan kesyan kapaḍa saja, maka adalah saja, minta dwa slèndang sutra, kapaụa twan, sebap saja dyata (skrivefejl for tyada) sakali punja slèndang, djwa adanja. Lain tyada ḍari saja, malèngken saja kirim tabé dan slamet parbanjak-banjak kapạ̣a twan, supajâ twan bar-olé slamet, dan tyaḍa kurang swatu apa-apâ, djwa adanja. Tartuli(verso)s di Tabanan, kapaḍa nem ari, bulan d̦ulkaiḍa, I850. Sahdan lagi saja ada dnger kabar, twan mawo blajar malèngken saja kasih slamet djalan sadjâ, kapaḍa twan, djwa adanja. Saja Njai Kenjèrx.

Oversættelse: „(Til) Hr. Lange, storkøbmand i Kuta på Bali i (riget) Badung.

Nu siger jeg Eder i dette brev, at tidligere, da jeg endnu ikke havde fået noget barn med Eder, lovede I mig, at når I fik to sønner vilde I finde et guldsmykke og en bælteplade til mig.

Derfor minder jeg Eder her om dette, da I nu har fået to sønner.

Og dernæst beder jeg Eder indtrængende om, hvis I elsker mig og har medlidenhed med mig, da at give mig en lille vogn som legetøj for Eders børn.

Dernæst beder jeg Eder indtrængende om, at det orgel, som I tidligere har skænket mig, nu må blive sendt tilbage.

Og dernæst, tilgiv mig, hvis I elsker mig og har medlidenhed med mig, vilde jeg bede Eder om to silketørklæder, fordi jeg slet ingen tørklæder har.

Og dernæst har jeg intet mere at sige Eder, undtagen at jeg sender Eder mange hilsener og ønsker, på det at det må gå Eder godt og I intet må savne.

Skrevet i Tabanan den 6. Dhulkaidah 1850 .

Dernæst har jeg hørt, at I vil foretage en sørejse, jeg onsker Eder blot god rejse. Fra mig, Njai Kenjèr."

Påskrift med blyant med Langes hånd: „fra min Balli Kone til mig -." 
Et dunkelt punkt i brevet er udtrykket kembang mas, som her er oversat ved "guldsmykke", men som ordret betyder "guldblomst" og som måske skal betegne en kunstfærdigt forarbejdet hårnål, men som også kan betegne et sæt knapper til en jakke. Ligeledes er det heller ikke klart, om afsenderinden ønsker det omtalte orgel tilsendt sig fra Langes hus, eller om hun ønsker det sendt tilbage til Lange fra sit eget hjem. For læserne af brevet, der vidste, hvor orglet befandt sig, var det naturligvis ganske klart, hvad hun ønskede.

Det fremgår således, at Langes første hustru hed Njai Kenjèr, og at hun boede $\mathrm{i}$ fyrstendømmet Tabanan, en omstændighed der måske siger noget om de forbindelser, som Lange havde i dette rige, hvor det ved flere lejligheder viste sig, at han havde stor indflydelse. De to sønner hed William Peter og Andreas Emil Lange. I sit testamente af 25. okt. $185^{1}$ (se derom Krarup Nielsens bog, de senere udgaver, eller mere udførligt i kronik af samme i „Politiken“ for $7 / 6$ 1927) kalder Lange dem sine „naturlige og anerkendte“ børn og betænker dem med hver 10,000 gylden. Af en tilføjelse til testamentet tre år senere fremgår det, at William Peter er død i mellemtiden, og Lange anser nu Andreas Emil som sin hovedarving og den, der skal føre hans virksomhed videre. Der blev intet deraf, eftersom handelsvirksomheden allerede i Langes sidste år var for nedadgående, og hans firma helt likvideredes i 1863 af nevøen Christian Lange, uden at der blev en øre tilovers til arvingerne. Men Andreas Emil, der havde fået en god uddannelse og var meget intelligent $\mathrm{og}$ dygtig, klarede sig udmærket. Han var i mange år sekretær hos den berømte Rajah Brooke, den engelske officer, hvem det lykkedes at blive fyrste af Sarawak på Borneo. Denne søn efterlod sig ni børn og talrige børnebørn.

De ønsker, afsenderinden fremfører overfor Lange, var for en mand af hans formue beskedne. Hun har åbenbart også bevaret en venlig indstilling overfor Lange, skønt han på det tidspunkt, hvor brevet blev skrevet, havde sin anden hustru, en kineserinde, boende hos sig i Kuta.

BREV II. Består af et enkelt lontarblad. Balinesisk sprog.

Transkription: (a) Twan punggawa besar, njahan i Siluné mapanangké luwas, galungan, depang, né tyang i twan, Pan Krabet, mwah

Billedtuderskrift til modstaende side: Samtidigt billede af Mads Lange malet af en balinesisk kunstner. Originalen $9 \times 14,8 \mathrm{~cm}$. Farverne er overvejende morke og lysegrå med enkelte rodbrune skygger og lidt blåt $\mathrm{i}$ håret. Ramme af tra, groft udskåret og delvis forgyldt. Lange er fremstillet $\mathrm{i}$ en heroisk positur, der også kendes fra balinesisk dansk. Originalen ejes af lærer, cand. jur. John Riis, Ølby Skole pr. Koge. 


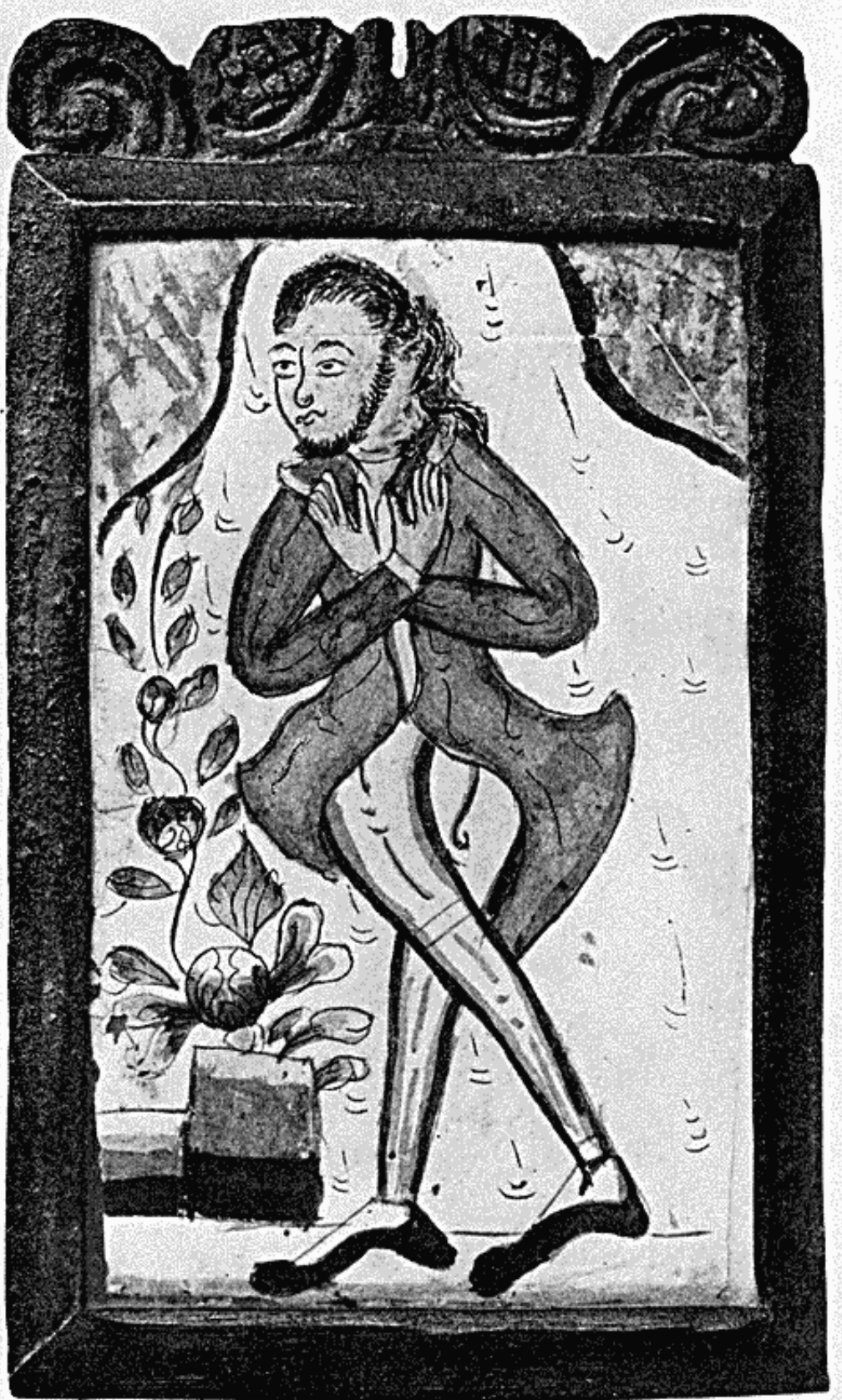


Pan Midjeng, djalanang ka Banjuwangi djani, ngiring utusan Tjokorḍ̣̣a iḍ̣a i Déwa Agung, bkelnć twan mangasih samadya. (b) Saja Ngurah Gdé.

Oversættelse: „Hr. Punggawa Besar, Silu vil ikke kunne komme afsted (ordret: om lidt Silu er forhindret at gå) (på grund af) Galungan (-festen), lad (ham derfor) ikke (tage afsted), Eders folk, Pan Krabet og Pan Midjeng, lad dem tage til Banjuwangi nu, som følgeskab for gesandte(r)n(e) fra Tjokorda ida i Dewa Agung; bring deres rejseforråd i orden. Fra mig Ngurah Gedé.“

Påskrift med blak med Langes hånd på forsiden: „Tuan Pangawa Bezar! Jeg beder Dem at lade et Fartøj være parat for at tage Gesandterne ombord fra Deva Agong, de vil vare hos Dem om 2 Dage, da vi ere nær ved Nytår beder jeg dem at forblive her og komme op til mig i Besøg."

Og på bagsiden af brevet efter underskriften: „(Rajah Kasiman) manu propia“, og under underskriften: „Sahaya mnoras gdéc.

Punggawa Besar: med denne halvt balinesiske, halvt malajiske titel menes øjensynligt Lange. Dewa Agung: fyrsten af riget Klungkung, hvem de øvrige balinesiske fyrster anerkendte som overherre, han var en direkte efterkommer af dynastiet fra Madjapahit, det mægtige hindurige på Java, der brød sammen 0 . I 500 for den islamitiske overmagt.

Afsenderens fulde navn har øjensynligt været Ngurah Gedé Kasiman, det var fyrsten af Badung, det rige, hvor byen Kuta med Langes faktori var beliggende. Denne fyrste, en klog og venlig gammel herre, var Langes gode ven. Det er sikkert rigtigt, at brevet - hvis skrift er mere skødesløs end i de tilfalde, hvor brevene er skrevet af professionelle skrivere er skrevet af fyrsten selv. Iøvrigt fremgår det af Langes påskrevne „oversættelse", at han hverken kendte den balinesiske skrift eller sproget særlig godt. Han lod øjensynligt brevene oversatte for sig fra balinesisk til malajisk, som han kendte bedre, og skrev så indholdet ned på dansk eller engelsk. Muligvis har han først på et senere tidspunkt foretaget disse påskrifter efter hukommelsen, i hvert fald har der indsneget sig nogle misforståelser.

BREv III. Består af et enkelt lontarblad. Balinesisk sprog.

Transkription: (a) Tuwwan Langc, né malu saja misalah i Djambot, kingsanang saja tkèn tuwwan, né djani déning ja suba ngrasa salah, $\mathrm{i}$ Djambot bwin budal saja tkèn tuwwan, déning i Djambot suba mulih ka Mangwi, da bwin tuwwan ngibukang ja, pang suba ja djumah di Mangwi. (b) Saja Njoman Majun. 
Oversættelse: „Hr. Lange, tidligere har jeg forvist Djambot, jeg har givet ham i Eders varetægt. Nu, eftersom han har bekendt sin skyld, kræver jeg Djambot tilbage igen fra Eder. Da Djambot allerede er vendt tilbage til Mangwi, behøver I ikke mere bekymre Eder om ham, thi han bor allerede i Mangwi. Fra mig Njoman Majun."

Påskrift med blyant ved Lange: „Mr. Lange; ther are a Slave men run away from you his Name are Jambot. I have taken him in my possession and wish to know your wishes and his fault - and if $\mathbf{i}$ shall send him back to you. I am Rajah Newam Maium“.

Dette brev giver et interessant indblik i de balinesiske retssadvaner, som de blev udøvet af fyrsterne, og Langes stilling dertil. Den balinesiske retspraksis kendte faktisk kun en straf, dødsstraffen, som blev idømt selv for ringe forseelser og omgående eksekveret, hvis da ikke en mand af rang eller magt intervenerede, i hvilket tilfaclde den dømte blev solgt som slave og sendt ud af riget. Det er sket, at Lange har frelst sådannc dødsdømte og taget dem i sin tjeneste (se Krarup Nielsens bog, I925, s. $7^{2}$ og 76 , og s. 87-88). Han betragtede dem ikke som slaver. Her er åbenbart tale om en sådan mand, som fyrsten igen har fået fingre $\mathrm{i}$ og nu ønsker at henrette, men han har så stor respekt for Lange, at han forst vil berolige denne, så han ikke mere skal bekymre sig om mandens skxbne. Den „oversættelse“, som Lange har givet, er ikke mindre interessant, for den er et vidnesbyrd om hans tolks diplomatiske evner! Tolken har drejet sagen hen til det punkt, at Lange netop skal sætte sig i forbindelse med fyrsten, naturligvis for at krave manden tilbage, et smukt forsøg på at frelse en landsmand ved Langes mellemkomst.

Angående Langes sprogbrug, se en udtalelse af baron van Hoëvell, der i året $\mathrm{I} 847$ besøgte Lange, anført i Krarup Nielsens bog, I925, s. 68: „hans sprog er en slags plattysk, vel overført til hollandsk, i så høj grad, det cr ham muligt, samt engelsk, der ganske vist ikke er rent, men dog i alt fald let forståcligt." At denne sprogforbistring også gælder Langes danske sprog, ses ligeledes af påskrifterne. Disse sproglige mangler har i praksis ikke haft videre betydning for Lange, der havde flere indfødte tolke og sekretærer i sin tjeneste, og som netop som ingen anden i kraft af sin personlighed var $\mathrm{i}$ stand til at opnå kontakt med de indfødte.

BREV IV. Et enkelt lontarblad. Balinesisk sprog.

Transkription: (a) Tuwwan Lange, né saja mbaang tuwwan tjaroring, dwang tgen, mwah tkèn i njonjah putu atgen, twan tundèn, saja mbaang ija, nanging tan sumapala pesan, kwala ada pabaang saja tkèn tuwwan. (b) Saja Byang Agung. 
Oversættelse: „Hr. Lange. Jeg giver Eder herved duku'er, to læs (hver på to kurve), og til Fruen et læs kager, vær I sendt af mig til at give dem til hende (d. v. s. vil I på mine vegne give dem til hende), men det har aldeles intet at betyde, det er kun en gave fra mig til Eder. Fra mig Biang Agung."

Påskrift med blyant ved Lange: „Mr. Lange. I sends you some frugtt which please asept. I am Vean Agong."

Duku er en slags frugt. Forsendelsen er en opmarksomhed til Lange og i lige måde til hans kinesiske hustru, som Lange ikke nævner i sin oversættelse. Hun hed Sang Nio, og Lange havde med hende en datter, Cecilie, der blev gift med Sultan Abu Bakar af Johore, se Krarup Nielsens bog, 3. opl., I94I, s. I36 o. v., samt kronik i "Politiken“ for 22/5 1927. Afsenderinden, Biang Agung, var enkefyrstinde af riget Mengwi, hun forekommer ligeledes $\mathrm{i}$ de to folgende breve.

BREV V. Et enkelt lontarblad. Balinesisk sprog.

Transkription: (a) Tuwwan Lange, saja matawu tuwwan, ada rentch jun ida Tjokorḍ̣a, ida i Déwa Agung Putra, daginga kna ada tundènan saja, marengin putusané saking Kalungkung, kma ka Banjuangi, saja ngiring jun ida Tjokordḍa, ida i Déwa Agung Putra, né tundènan saja, adjaka dadwa, maadan i Begbeg, mwah i Jandar, pangidih saja tkèn (b) tuwwan, apang tuwwan ningkahang ija, bakal mambwatang ka Banjuangi. Saja Byang Agung Ktut Agung.

Mangdé ja bareng tkèn putusané saking Kalungkung, mwah déning saja abdik mekelin ija uli di Mangwi, makwangannjané ija bkel, twan pabaatin saja bkelnjané, mwah sangunnjané ditu, sanjandang-njandangan tjalona di Banjuangi, kwala pang twan ngitungang né tlahanga.

Oversættelse: „Hr. Lange, jeg meddeler Eder, at der er dalet et ønske ned fra Tjokorda ida i Déwa Agung Putra, af det indhold, at der skal vare sendebud fra mig til at ledsage Klungkung-gesandte(r)n(e) did til Banjuwangi. Jeg folger Tjokorda ida i Déwa Agung Putra's ønske; mine sendebud er to unge mennesker ved navn Begbeg og Jandar. Min bøn til Eder er, at I sørger for at bringe dem til Banjuwangi. Fra mig Biang Agung (og) Ketut Agung.

Ifald de tager med Klungkung-gesandte(r)n(e), og fordi jeg kun har givet dem liden fortæring med fra Mangwi, hvad de måtte mangle af fortæring, giv dem det på mine vegne (ordret: lav I for mig megen deres fortæring), og deres føde dér, såmeget som er tilstrækkeligt for den tid, de vil komme til at tilbringe i Banjuwangi; hvad de forbruger, må I blot fore på min regning." - Brevet er uden påskrift. 

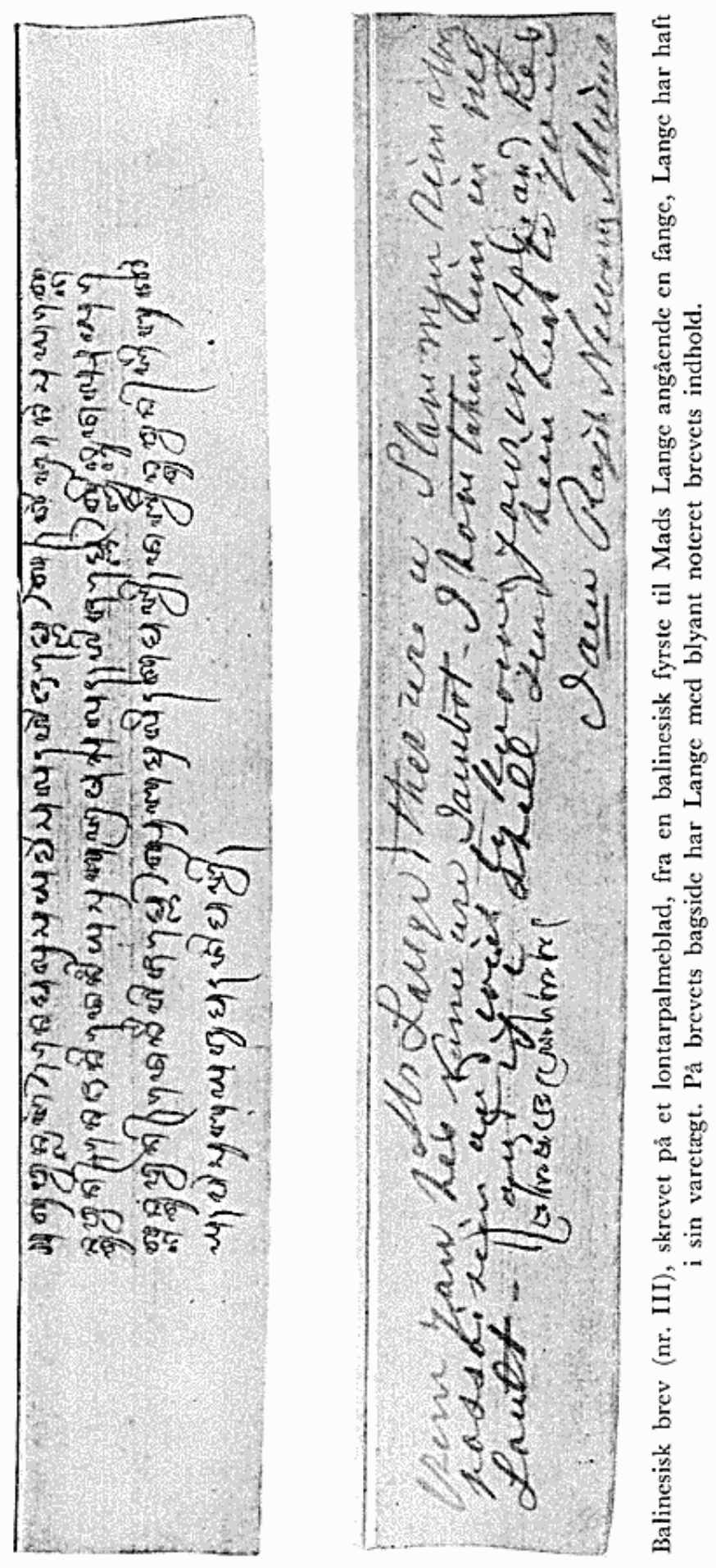
Afsenderinden af dette brev, Biang Agung, er den samme som i brev IV, enkefyrstinden af Mengwi. Medunderskriver er Ketut Agung, den regerende fyrste af Mengwi, han blev konge efter at have myrdet sin broder, Biang Agung's agtefælle. Men enken vedblev at have stor indflydelse i rigets affarer. Tjokorda ida i Déwa Agung Putra er navn og titel på fyrsten af Klungkung, se brev II. Byen Banjuwangi ligger på østspidsen af Java, i den fandtes den nærmeste hollandske embedsmand, en fungerende Assistent-resident. Muligvis er der tale om sendelsen af de samme gesandter, som fyrst Kasiman af riget Badung omtaler i brev II. Hvad der ligger bag deres sendelse oplyses ikke, men denne er under alle omstændigheder en sag af vigtighed, fordi de er udsendt af de balinesiske fyrsters overherre, fyrsten af Klungkung.

Brev VI. Et enkelt lontarblad. Balinesisk sprog.

Transkription: (a) Tjai Lange, i Lange mambaang ira tulis, isinja, baan ada njuh ira dini di Kwalu, laad aturané uli dini di Badung, né djani i Lange mapangidihan tkèn ira, mambeli njuh wowona tkèn ira, ira using nawajang nalepèk buka isin tulis i Langené tkèn ira, ira suba maaturing ida Mémé Agung Istri, nunasang i Lange njuh wowona, né djani ida Mémé Agung Istri, ira, mambaang i Lange ngidih njuh wowona, (b) mwah ira mapangidihan tkèn i Lange, kna i Lange mambeliang ira bụil dwang koḍi. Ira Ktut Agung. Né suba mulih tkèn idep i Langené, jèn baan pambelinnjané, di suban tka bọilé bwin mapaitungan.

Oversættelse: „Du, Lange, har sendt mig et brev, indeholdende: Hvad angår mine kokospalmer her i Kwalu, i sin tid tilbudt herfra $\mathrm{i}$ Badung, nu beder du mig om at måtte købe kokosnødderne af mig. Jeg vil ikke tinge om prisen, men retter mig ganske efter dit brev til mig. Jeg har talt til Mémé Agung Istri for at bede om kokosnødderne til dig, Lange. Nu bevilger Mémé Agung Istri og jeg de af dig udbedte kokosnødder. Og jeg beder dig, Lange, om at købe $4^{o}$ geværer til mig. Jeg, Ketut Agung. Salgsprisen overlader jeg til dit forgodtbefindende, når geværerne er kommet, afregner vi."

Påskrift med blyant ved Lange: „Du Lange vil have mine Cocosnøder jeg har 30,000 til vhilke du er velcomen. (Deva [rettet til Anak] Agong)."

Afsenderen er Ketut Agung, fyrsten af Mengwi, se brev V. Lange har i sin påtegning øjensynligt vaklet mellem, om afsenderen var Deva Agung, fyrsten af Klungkung, se brev II, eller Anak Agung, fyrsten af Mengwi, et forhold, der iøvrigt tyder på, at påskriften er foretaget på 
et senere tidspunkt end modtagelsen af brevet, måske $\mathrm{i}$ hans sidste år, hvor Lange, der følte, at enden nærmede sig og ønskede at rejse hjem, på flere måder beskikkede sit hus, og måske da har gennemgået sit brevarkiv og foretaget disse påskrifter efter hukommelsen. Det fremgår imidlertid af brevets tekst, at afsenderen er fyrsten af Mengwi, hvis fulde navn og titel var Anak Agung Ketut Agung. Kwalu ligger sikkert et sted ved kysten, og forholdet er nok det, at Lange tidligere for fyrsten af Mengwi har plantet kokospalmer dér, som han nu vil købe frugterne af. Lange havde indrettet en oliemølle ved sit faktori og var meget interesseret $\mathrm{i}$ at fremskynde produktionen af kokosnødder. Fyrsten har, for han giver sit tilsagn, rådspurgt Mémé Agung Istri, som er identisk med Biang Agung, afsenderinden af brevene IV og V, og han benytter her ordet maatur, der betyder at tale til en højerestående. Tallet 30,00o står ikke i brevet, det var naturligvis Lange bekendt. Geværerne udelader han klogeligt i sin oversættelse, som den hollandske regerings repræsentant på Bali kunde han naturligvis ikke så godt sælge våben til en indfødt regent.

Foruden de ovenstående seks breve findes der nogle få stykker af samme karakter, som ligeledes er behandlede af Dr. Voorhoeve, og det vil vare naturligt også at fremføre disse i denne forbindelse.

Det ene findes på Nationalmuseets etnografiske samling under signaturen C. a. I25. Bagsiden med 3 linjer tekst, underskrift, samt det balinesiske tal for 50 , er afbildet i Krarup Nielsens bog, 1925, s. I 72, samt i en artikel om de af Mads Lange til Nationalmuseet skænkede etnografiske genstande i „Fra Nationalmuseets Arbejdsmark“, 1954, s. 94 . Dette brev er sarlig interessant derved, at Mads Lange selv er afsenderen. Brevet består af et enkelt lontarblad, sproget er pidgin-malajisk, skriften balinesisk. Det er naturligvis ikke skrevet af Lange selv, men af en skriver. Iøvrigt frembyder tydningen visse vanskeligheder.

Transkription: (a) Radjâ Ngûra hagung Tabanan, sadikit hari lagi saja mulaï djalan pulang saja punja negri, saja punja badan tara énak, djadi saja tra bolih dengen badan kasih saja punja tabé, sama ratu, tapi trima skarang disini, saja punja slamet tinggal saja tida bolih katta lain, apa jang saja punja matta jang suda lijat, dari orang Bali, tida ada orang jang knal saja punja hati, punja tjinta saperti ratu, bapa saja punja Ala, saja pulang taknal apa-apa, nanti ratu denger kumba (b) li kabar dari saja, sablah dunyana, kapan ratu suka, ratu punja nama, tulis dalem glas, kirim sama saja, bagimana saja jang bolih bikin bagus, 
tinggal salamanja sobat sama saja punja sodara, saja tinggal ba(gi)tu djuga, Lange.

Oversættelse: „Radja Ngurah Agung af Tabanan. Om få dage tiltræder jeg rejsen til mit land. Mit legeme er ikke rask, så jeg kan ikke personlig sige farvel til Deres Højhed, men modtag nu her mit farvel. Jeg kan ikke udtale mig på anden måde (d. v. s. udtrykke, hvad jeg føler, på anden vis, end at efter) alt, hvad mine øjne har set, så er der blandt Balis folk ingen, der kender mit hjerte og mit sind (så godt) som Deres Højhed (og?) min Fader Gud. Jeg rejser hjem med alt i min erindring. Deres Højhed vil snart høre fra mig igen fra den anden side af verden. Hvis De synes, da skriv Deres navn i glas (betyder formodentlig på en genstand, der kan indrammes bag glas) og send mig det, at jeg kan gøre en smykkegenstand deraf. Forbliv stedse en ven af min broder, som jeg forbliver Deres (ven). Lange."

En påskrift med blyant har desuden stået nederst på brevets bagside. Så vidt det kan ses, er det ikke Langes hånd, den er iøvrigt næsten udslettet og intet ord lader sig tyde deraf.

Brevet er stilet til fyrsten af riget Tabanan, som var Langes gode ven. Det er ment som et afskedsbrev og viser, at Langes helbred på dette tidspunkt var nedbrudt, og at han påtænkte at bryde op og vende hjem til Danmark. Virksomheden skulde da fortsattes af hans broder, Hans Lange, der var hans medarbejder. Brevet er sikkert aldrig kommet fyrsten i hænde, Lange er død forinden, og brevet blev bragt til Danmark af en dansk kaptajn Strandgaard sammen med forskellige andre gaver fra Lange til Nationalmuseet. Der er i brevet en fin hjertelig tone, men man aner også, at det er skrevet af en mand, der er klar over, at hans bedste dage er forbi.

To andre breve i hollandsk besiddelse er fremdraget af Dr. Voorhoeve, der har været så venlig at sende biblioteket fotokopier deraf.

Det ene findes i Amsterdam, Koninklijk Instituut voor de Tropen, signeret MS. A. 4848 d. Det består af et enkelt lontarblad.

Transkription: (a) Tjai twan Lange, tjai mambaang bapa tulis, daginga, baan ada pakakirim, i Twan Djungkahir pan Kapélan, asistèn resdèn Banjwangi, praja tiba tkèn bapa, lwirnjané baludru mirah, baludru tjmeng, suba mabongkos dadi absik, makatanda pitresnan idepnjané tkèn bapa, né djani pakakirimé pisukajang tjai tkèn bapa, suba tka tkèn bapa, daat baan bapa njuksmajang, pitresnannjané i Twan Djungkahir pan Kapélan, masawitra tkèn bapa, mwah bapa mambwattang mapangidihan tkè(b)n tjai, déning baludruné né tjmeng, kwangan 
binakikit (for: bin akikit) osing ada bakalima (for: bakal lima), né djani [ba] bapa sang Gdé Madé Rai, pamisakittang tkèn tjai, tjai idihin bapa baludru tjmeng bwinakikit (for: bwin akikit), pinganan dadi panjaglup limané makadadwa, mangdé kasiddan idep bapané nggaé badju, jèn suba tjai mambaan, titipin bapa tked djumah di Kalungkung.

Oversættelse: „Hr. Lange. Du har skrevet et brev til mig om, at der er en forsendelse fra Jonkheer van Capellen, Assistent-resident i Banjuwangi, bestemt til mig og bestående af rødt fløjl og sort fløjl sammen i een pakke, som tegn på hans bevågenhed for mig. Nu har I givet mig den forsendelse, og den har nået mig. Jeg forstår til fulde den bevågenhed (eller: jeg takker for den bevågenhed), som Jonkheer van Capellen narer for mig. Nu har jeg indtrængende en anmodning at gøre dig. Det sorte fløjl er ikke helt nok, der er ikke til ærmerne. Nu ulejliger jeg, sang Gdé Madé Rai, dig med den anmodning, at du vil bede om noget mere sort fløjl til mig, nok til at tjene til manchetter (ell. lgn., oversætelsen kun en formodning) til begge armer, så at mit ønske om at lave en jakke af det kan blive helt opfyldt. Når du har modtaget det, så send det hjem til mig i Klungkung."

Påskrift med blæk, ikke med Langes hånd, men måske skrevet over en påskrift af ham: "Letter from Padanda". Iøvrigt tydelige rester af en længere påskrift med blyant med Langes hånd, hvoraf kun enkelte ord kan leses: "Capellan", og: „he wants more", øjensynlig rester af en af Langes sædvanlige påskrifter med oversættelse og gengivelse af brevets indhold.

Afsenderen af brevet kaldes i påskriften Padanda. Ordet er afledet af Sanskrit og betyder "stavbærer". Det er på Bali betegnelsen for de øverste præster, der bærer en lang stok som tegn på deres værdighed (smlgn. Krarup Nielsens bog, 1925, s. 82-83). Afsenderen af brevet er øjensynlig en sådan brahmanpræst, måske endda selve ypperstepresten i fyrstendømmet Klungkung. Jonkheer F, van Capellen er den samme person, der har udfardiget Mads Langes testamente af $\mathrm{i} 85^{\mathrm{I}}$, se brev I, han omtales i regeringsalmanakken $1849^{-52}$ som Assistent-resident-vikar i Banjuwangi på Java og $1850-52$ tillige som kommitteret for sager vedrørende Bali og Lombok.

Det sidste brev findes på Universitetsbiblioteket i Leiden og er signeret Cod. Or. 306 I a. Det er ikke stilet til Lange, men han omtales deri.

Transkription: (a) I bapan Mrassanâ, kna iba ngorahin i twan Kli, pang ngadajang lajarrang sakonjarri (der kan også læses sakonjarré) twan Langené, jan ja tka i twan Langa (-a udtales -e på balinesisk, derfor 
kan Lange skrives Langa, men med suffix må det blive Langené), kna ja nunḍèn atpuk ring kai maglah pjannak, i Gḍé Raka, i Gụé Putu. (b) Kai Ngurah Kasiman, kai Ngurah Pamtjuttan.

Brevet er beskrevet og indholdet refereret i H. H. Juynboll: Supplement op den Catalogus van de Sundaneesche Handschriften ... 1912, s. I54-I55 på folgende måde: „Brev på Nedre balinesisk, skrevet på et lontarblad, på de to radja'er af Badung Ngurah Kasiman og Ngurah Pamtjuttan's vegne og adresseret til en vis Mrasana. Denne skal meddele $\mathrm{Hr}$. Kli (?), at Hr. Langes skonnert bør sejle ud og at, når denne sidste (Lange) er ankommet, vil han have at indbyde til sig prinserne Gdé Raka og Gdé Putu."

Brevet er uden påskrift, det har jo næppe heller været i Langes eje. Fyrst Kasiman af riget Badung er kendt fra brev II. Han havde en medregent Radja Ngurah Pamtjuttan, omtalt bl. a. i G. Lauts: Het Eiland Balie en de Balinezen, Amsterdam 1848, s. 136 .

Dette er, hvad der er blevet tilbage af et sikkert righoldigt arkiv af lignende breve, som Lange har haft hos sig i sit faktori i Kuta på Bali. Det er beklageligt, at ikke mere er blevet bevaret deraf. Hvor lapidariske i deres stil og indhold disse breve end er, så siger de ikke så lidt om forholdene på øen på et tidspunkt, hvor curopæisk kultur endnu ikke havde forårsaget større omvæltninger. $\mathrm{Og} \mathrm{om}$ Mads Langes stilling og indflydelse er de jo meget sigende.

Man må håbe, at Krarup Nielsens bog om denne usædvanlige sømand og handelsmand engang må komme i en ny og udvidet udgave, hvor dette ny kildemateriale, som takket være Dr. P. Voorhoeve's indsats nu er lettilgangeligt, er taget med i betragtning. 